\title{
Administration of a Polyphenol-Enriched Feed to Farmed Sea Bass (Dicentrarchus labrax L.) Modulates Intestinal and Spleen Immune Responses
}

\author{
Thea Magrone, ${ }^{1}$ Sergio Fontana, ${ }^{2}$ Flavia Laforgia, ${ }^{2}$ Teresa Dragone, ${ }^{1}$ \\ Emilio Jirillo, ${ }^{1}$ and Letizia Passantino ${ }^{3}$ \\ ${ }^{1}$ Department of Basic Medical Sciences, Neuroscience and Sensory Organs, University of Bari, 70124 Bari, Italy \\ ${ }^{2}$ Farmalabor Srl, 76012 Canosa di Puglia, Italy \\ ${ }^{3}$ Department of Emergency and Organ Transplantation, University of Bari, 70124 Bari, Italy \\ Correspondence should be addressed to Emilio Jirillo; emilio.jirillo@uniba.it
}

Received 1 July 2015; Revised 27 August 2015; Accepted 2 September 2015

Academic Editor: Jara Perez-Jimenez

Copyright (c) 2016 Thea Magrone et al. This is an open access article distributed under the Creative Commons Attribution License, which permits unrestricted use, distribution, and reproduction in any medium, provided the original work is properly cited.

\begin{abstract}
Farmed fish are exposed to a continuous antigenic pressure by microbial and environmental agents, which may lead to a condition of chronic inflammation. In view of the notion that polyphenols, largely contained in fruits and vegetables, are endowed with antioxidant and anti-inflammatory activities, farmed sea bass (Dicentrarchus labrax L.) have been administered with red grape polyphenol-enriched feed. Polyphenols were extracted from the seeds of Canosina Nero di Troia Vitis vinifera and mixed with conventional feed at two different concentrations (100 and $200 \mathrm{mg} / \mathrm{kg}$, resp.). Fish samples collected at days 223 and 273, respectively, were evaluated for intestinal and spleen cytokine release as well as for spleen macrophage (MØ) and melanomacrophage center (MMC) areas and distribution. Data will show that in treated fish decrease of intestinal interleukin- (IL-) $1 \beta$ and IL- 6 and increase of splenic interferon- (IFN-) $\gamma$ occur. On the other hand, in the spleen reduction of MØ number seems to parallel increase in MMCs. Collectively, these data suggest that polyphenol-administered sea bass generate lower levels of intestinal proinflammatory cytokines, while producing larger amounts of spleen IFN- $\gamma$, as an expression of a robust and protective adaptive immune response. Increase of MMCs corroborates the evidence for a protective spleen response induced by feed enriched with polyphenols.
\end{abstract}

\section{Introduction}

It is well known that fish immune cells mainly include lymphocytes, dendritic cells, monocytes, macrophages, granulocytes, and thrombocytes [1]. In teleost fish, major lymph reticular tissues are head kidney, spleen, thymus, liver, and mucosa-associated lymphoid tissues as in the gut [2]. Accordingly, these tissues may represent the primitive analogues of fish lymph node germinal centers, even if their morphology and immune function are still under investigation [3-6].

In fish, melanomacrophage centers (MMCs) are defined as a group of pigmented macrophages (MØ) under form of a nodular cluster of $M \emptyset$ characterized by heterogeneous inclusions such as degradation products of cells [7]. MMCs are devoted to the destruction and recycling of exogenous and endogenous antigens [8], even including storage of iron as a consequence of erythrophagocytosis [9]. All these processes generate cell debris, melanin pigments, hemosiderin granules, and lipofuscin residues [10], as well as lipid droplets, basic protein aggregates, and neutral mucopolysaccharides [11]. Moreover, some types of intracellular granules contain trace metals [12-15]. The pigment deposits contained in vacuoles suggest a mechanism of phagocytosis by MMCs as an expression of early antimicrobial defenses [16-18].

Number, size, and pigment distribution of MMCs depend on fish species [19, 20], organs [11, 21, 22], age [23-25], sexual activity [26, 27], nutritional status, and fish health [10, 28-31].

The growth of aquaculture, associated with the intensification of production systems, has increased the demand for high-quality feedstuff in order to improve fish health without any side effects for consumers [32, 33]. Fish meal has traditionally been used as the main feed ingredient in 
preparation of fish feed, due to its high protein content and balanced amino acid profile. Because of its recent shortage in global production, coupled with increased demand and competition for its use in livestock and poultry feeds, prices of fish meal have become unaffordable [34]. Therefore, sustainable aquaculture depends on a perfect balance between growth and healthy conditions of fish. The use of antibiotics and chemotherapeutics to combat fish infections may generate resistant pathogens, bioaccumulation, and environmental pollution. Furthermore, commercial vaccines are expensive for fish farming practices and must be specific against particular pathogens [35].

Nowadays, use of plant proteins to replace fish meal without reducing the performance has started. The administration of probiotics and prebiotics to fish seems to favor the growth of a protective microbiota $[36,37]$, which, for its immunomodulating activities, may represent a very promising biological control for aquaculture. Therefore, investigations of spleen MMCs have provided useful knowledge on the fish health status also in relation to the type of nutrition [3843].

Among natural products, polyphenols, largely present in fruits and vegetables, have been shown to scavenge oxygen and nitrogen derived free radicals, modulating antioxidant enzymes and cellular redox transcription factors [44]. In particular, the protective effects of polyphenols consist in the continuous removal of various reactive oxygen species from cells, such as singlet oxygen, peroxynitrite, and hydrogen peroxide in order to maintain healthy metabolic functions [45]. They may also affect cell-to-cell signaling, receptor sensitivity, inflammatory enzyme activity, or gene regulation $[46,47]$. According to our own studies in both animal models and humans polyphenols from red grapes are endowed with antioxidant and anti-inflammatory activities, also keeping in equilibrium the immune machinery $[48,49]$.

A few studies have been conducted on the use of polyphenols in farmed fish in order to evaluate their antioxidant and anti-inflammatory effects. One study investigated the in vitro effects of resveratrol, mangiferin, and (-)-epigallocatechin-3gallate on the histiophagous ciliate Philasterides dicentrarchi, which causes fatal scuticociliatosis in farmed turbot Scophthalmus maximus L. Of the 3 polyphenols, resveratrol showed strongest antiprotozoal activity, reducing ciliate density after 1-week culture. In view of these findings, the potential utility of chemotherapy with polyphenols as a strategy for the control of scuticociliatosis in farmed turbot has been emphasized [50].

In another research, the beneficial effects of polyphenols derived from waste water from an olive mill, obtained by nonplastic molecular imprinting device, were evaluated in a hypercholesterolemic diet on Carassius auratus, commonly known as goldfish, that was selected as experimental model. Results show the beneficial activity of polyphenols with a reduction of the damage in the steatotic group, confirming that they may be used for the treatment of diseases by lipid accumulation in feed of farmed fish. This dietary approach may improve the organoleptic and nutritional quality. Finally, the beneficial effects of waste oil extract should be suggested in the context of research programs focused on the products to the health system [51].

In the present study, in farmed sea bass (Dicentrarchus labrax L.) the effects of a diet rich in polyphenols on the cytokine release from gut and spleen tissues as well as deposition of MMCs in spleen were evaluated.

\section{Materials and Methods}

2.1. Polyphenol Extracts. Canosina red grape from Nero di Troia is an autochthonous Vitis vinifera grape cultivar which grows in Apulia (South Italy). It is characterized by thick skinned and small sized berries. Frozen seeds from berries were extracted by percolation using ethanol/water $(70: 30)$. Then, the extract was first analyzed by means of liquid chromatography with diode array detection to define the polyphenol composition. Thereafter, the extract was purified on a synthetic adsorbent brominated resin and percentage of polyphenol content was determined.

The extracts were evaluated for their potential antioxidant effects by using the 2,2-diphenyl-1-picrylhydrazyl assay which measures the ability of test agents to scavenge radicals [52].

2.2. Preparation of Feed and Dietary Regimen. Fish diet consisted in conventional feed mixed with two different concentrations of grape extracts, administered 3-4 times a day:

(1) Fish $(n=30)$ fed mix composed of $50 \mathrm{~g}$ of grape extracts in $5 \mathrm{~kg}$ of cornstarch, namely, $10 \mathrm{~g}$ of mix (100 mg of extract) for $1 \mathrm{~kg}$ of conventional pellet (100 mg/kg).

(2) Fish $(n=30)$ fed mix composed of $100 \mathrm{~g}$ of grape extracts in $5 \mathrm{~kg}$ of cornstarch, namely, $10 \mathrm{~g}$ of mix (200 mg of extract) for $1 \mathrm{~kg}$ of conventional pellet $(200 \mathrm{mg} / \mathrm{kg})$. For preliminary experiments, lower concentration of grape extracts, for example, 1,10 , and $50 \mathrm{mg} / \mathrm{kg}$, was not effective in our test system.

Controls $(n=30)$ were represented by fish fed conventional feed.

2.3. Sample Collection. Spleen samples were collected from a total of 90 immature (juvenile) samples of sea bass reared in captivity in a farm near Lesina lake (Foggia, Italy). Sample collection took place during winter at 223 days (T1) and 273 days (T2) from the beginning of the experiment.

Fish, reared in experimental conditions, were treated according to the "Council Directive 86/609 EEC for the protection of animals used for experimental and other scientific purposes" and the "Ethical Justification for the Use and Treatment of Fishes in Research" [53].

2.4. Immunological Investigations. Specimens were taken from spleen and both pyloric (P) and terminal (T) gut $(\mathrm{G})$ segments of treated and untreated fish, respectively.

Gut portions were placed in Petri dishes containing RPMI 1640 (Miltenyi Biotec, Bergisch Gladbach, GE) plus 
streptomycin (100 mg/mL) (Biowhittaker, Walkersville, USA) and $1 \%$ penicillin (Biowhittaker) and sliced with scissors to obtain GP and GT samples, respectively. Both segments were then incubated in Petri dishes containing RPMI 1640 for 2 and $24 \mathrm{~h}$ at $14^{\circ} \mathrm{C}$, respectively. Afterwards, supernatants of GP and GT cultures were obtained by centrifugation at $10,000 \times \mathrm{g}$ for $10 \mathrm{~min}$ at $4^{\circ} \mathrm{C}$ and stored at $-30^{\circ} \mathrm{C}$, until use.

Spleen specimens were placed in Petri dishes containing RPMI 1640 plus $0.2 \%$ heparin and passed through a cell strainer with a $70 \mu \mathrm{m}$ nylon membrane (Becton Dickinson, Bedford, MA), gently forced with a $1 \mathrm{~mL}$ syringe plunger, and filtered in medium, to yield a single cellular suspension for each case. After incubation for 2 and $24 \mathrm{~h}$ at $14^{\circ} \mathrm{C}$, respectively, $1 \mathrm{~mL}$ of cell cultures was put into Eppendorf cups and centrifuged at $10,000 \times \mathrm{g}$ for $10^{\prime}$ at $4^{\circ} \mathrm{C}$. Finally, culture supernatants were collected and stored at $-30^{\circ} \mathrm{C}$, until use [54].

Concentrations (pg/mL) of fish interleukin- (IL-) $1 \beta$, IL6 , and interferon- (IFN-) $\gamma$ in supernatants were determined by specific ELISA kits (Cusabio Biotech Co., Wuhan, Hubei, China) according to manufacturer's instructions. Cytokine concentrations were read at $550 \mathrm{~nm}$ by means of an ELISA reader (iMark Microplate Absorbance Reader, BioRad, Hercules, California, USA). Concentrations obtained for each cytokine were multiplied by the dilution factor to obtain sample values.

2.5. Basic Histology and Histochemistry. All fishes were anaesthetized with Tricaine 1:5000 (Fluka BioChemika, Buchs, Switzerland) according to the guidelines for Euthanasia of Nondomestic Animals American Association of Zoo Veterinarians (2006). GP, GT, and spleen of each fish were removed, fixed in $10 \%$ buffered formalin, later washed in running water, dehydrated in increasing ethanol concentrations, and embedded in paraffin wax.

Sections of tissue ( $5 \mu \mathrm{m}$ thick) were processed for the following: (a) Hematoxylin-Eosin (H\&E) staining (Merck, Darmstadt, Germany); (b) Perls-Van Gieson staining (BioOptica, Milan, Italy) to identify ferric iron; (c) Mallory staining (Merck, Darmstadt, Germany) to detect lipofuscin pigments and ceroids. The identification of $\mathrm{M} \varnothing$ was performed using the $\alpha$-Naphthyl Acetate Esterase (Anae) (Sigma Diagnostics, St. Louis, MO, USA) and Peroxidase (Perox) (Sigma Diagnostics) methods.

2.6. Quantification of Melanomacrophage Centers. The surface occupied by MØ and MMC ( $\mu \mathrm{m}^{2}$ spleen parenchyma) was counted and measured randomly for a number of 100 elements, selected at digital fields. Each digital field was photographed with a $40 \mathrm{x}$ objective with a digital camera (XC003P, Sony, Tokyo, Japan) connected to a light microscope (Laborlux 12, Leitz, Wetzlar, Germany). Measurements were performed using an image analysis software (QWin, Leica, Cambridge, England).

2.7. Statistical Studies. Statistical differences for concentrations of cytokines from gut and spleen tissues after 2 and $24 \mathrm{~h}$ incubation, respectively, between untreated and treated samples, both at T1 and T2, and number and surface occupied by $\mathrm{M} \varnothing$ and MMCs were compared. Statistical analysis was performed using the GraphPad Prism statistical software release 5.0 for Windows Vista. Bonferroni's test was used for comparison between controls and treated samples. Statistical significance was set at $P<0.05$.

\section{Results}

As far as the polyphenol content of the red grape extracts is concerned percentages were the following: proanthocyanidins (101.8\%) and catechins plus epicatechin (10.37\%).

(a) Cytokine Release from Gut and Spleen following $2 \mathrm{~h}$ Incubation. With regard to GP supernatants, concentrations of IL-1 $\beta$ are represented in Figure 1(a). At T2, in treated samples amounts of IL-1 $\beta$ were significantly lower than those observed in the respective controls. No differences were noted in relation to polyphenol concentrations used.

Results related to determination of IL- $1 \beta$ in GT supernatants are expressed in Figure 1(b). A significant increase in IL- $1 \beta$ was observed at T2 with $100 \mathrm{mg} / \mathrm{kg}$ polyphenol dose in comparison to other treated samples.

With regard to spleen IL-1 $\beta$ production, no significant differences between the various samples were detected (data not shown).

Determination of IL- 6 in the GP supernatants is represented in Figure 2(a). In untreated samples, an increase in IL-6 levels was noted at T1 in comparison to T2. In treated samples with both concentrations of polyphenols levels of IL-6 decreased in a statistically significant manner at T2 versus T1. However, values of these treated samples were not significantly different from those of controls at the same time points.

With special reference to GT supernatants, IL-6 determination is depicted in Figure 2(b). In untreated samples, an increase in IL-6 levels was noted at T1 in comparison to T2. In the case of treated samples, T2 values of IL- 6 were lower than T1 levels using $100 \mathrm{mg} / \mathrm{kg}$ of polyphenols. However, T1 values with $200 \mathrm{mg} / \mathrm{kg}$ were lower than the respective untreated counterpart.

With regard to spleen IL-6 production, no significant differences between the various samples were observed (data not shown).

In the GP supernatants, IFN- $\gamma$ levels decreased at T1 in treated samples with $200 \mathrm{mg} / \mathrm{kg}$ dose in comparison to T2 controls (data not shown). In Figure 3(a), at T2, levels of IFN- $\gamma$ released from GT were higher with $200 \mathrm{mg} / \mathrm{kg}$ dose in comparison to the same concentration at $\mathrm{T} 1$.

At T2, spleen IFN- $\gamma$ release significantly increased in all samples considered (Figure 3(b)). However, at T2, levels of IFN- $\gamma$ in fish treated with $200 \mathrm{mg} / \mathrm{kg}$ were significantly higher than those observed at $\mathrm{T} 1$ in both treated and untreated samples.

(b) Cytokine Release from Gut and Spleen following $24 \mathrm{~h}$ Incubation. In GP supernatants, at T2, IL-1 $\beta$ concentrations 


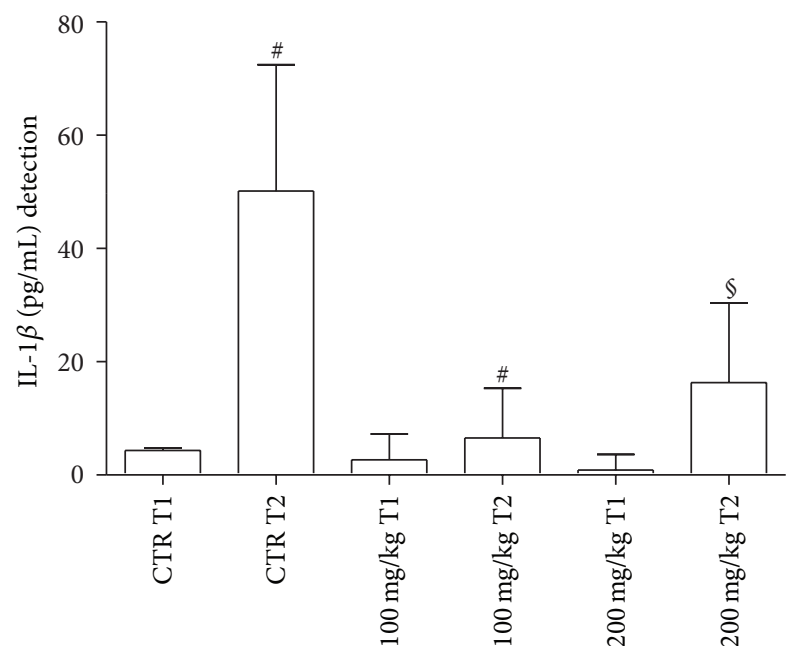

(a)

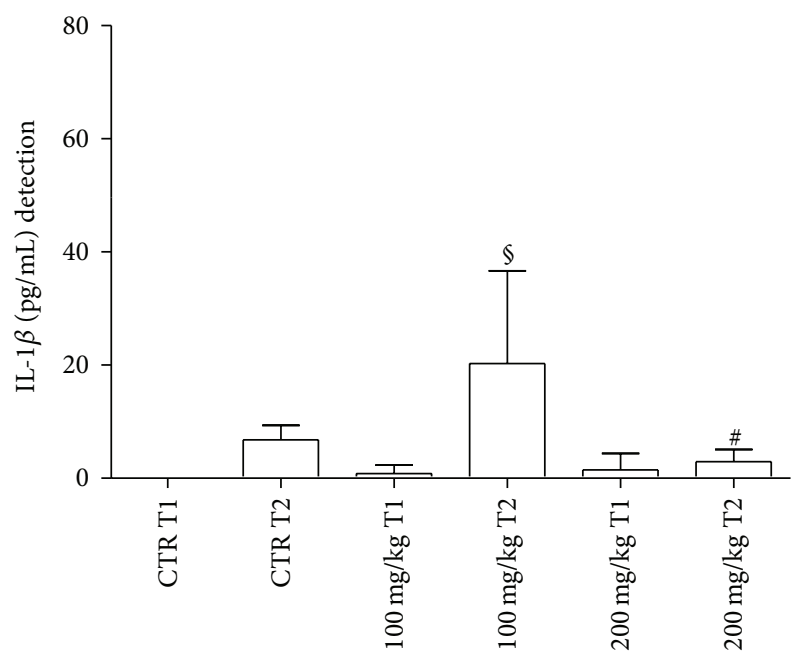

(b)

FIGURE 1: Fish IL-1 $\beta$ levels from GP (a) and GT (b) supernatants after $2 \mathrm{~h}$ incubation. CTR = untreated samples; T1 = before treatment; $\mathrm{T} 2=$ at the end of treatment. Statistical analysis was performed using the GraphPad Prism statistical software release 5.0 for Windows Vista. Bonferroni's test was used for comparison between the controls and treated samples at both concentrations. Statistical significance was set at $P<0.05$. (a) ${ }^{\#} P<0.0001$ CTR T1 versus CTR T2; ${ }^{\#} P<0.0001$ CTR T2 versus $100 \mathrm{mg} / \mathrm{kg} \mathrm{T2} ;{ }^{\S} P<0.01 \mathrm{CTR}$ T2 versus $200 \mathrm{mg} / \mathrm{kg}$ T2. (b) ${ }^{\S} P<0.01100 \mathrm{mg} / \mathrm{kg}$ T1 versus $100 \mathrm{mg} / \mathrm{kg} \mathrm{T} 2 ;{ }^{*} P<0.05100 \mathrm{mg} / \mathrm{kg}$ T2 versus $200 \mathrm{mg} / \mathrm{kg} \mathrm{T} 2$.

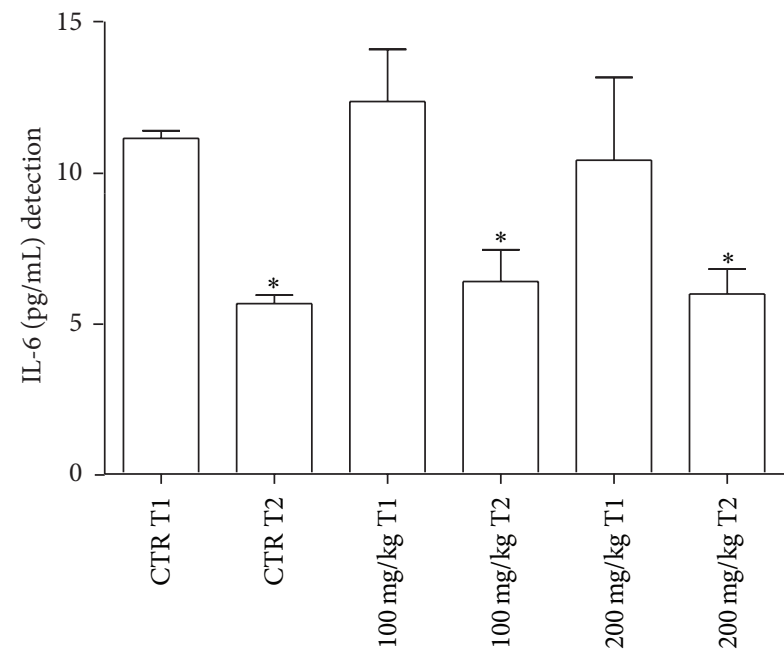

(a)

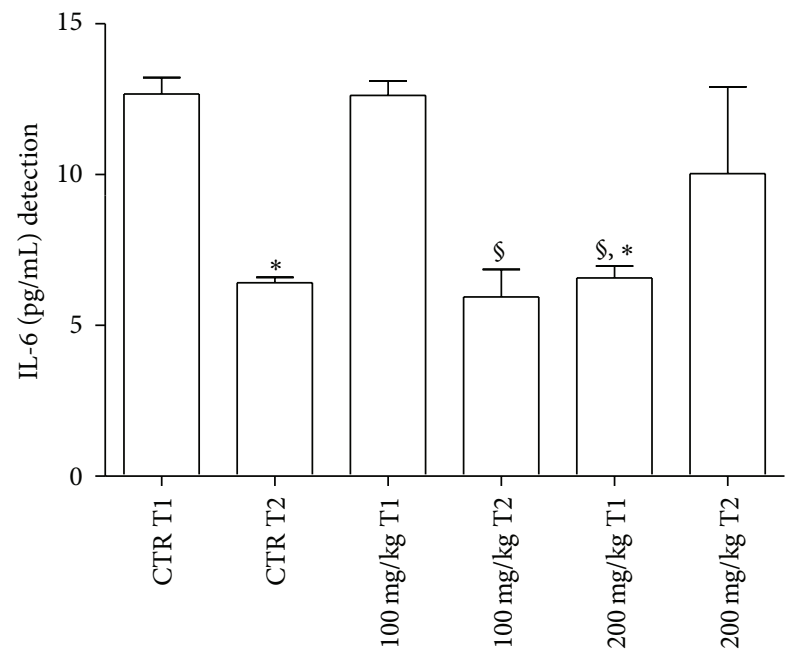

(b)

FIGURE 2: IL-6 levels released from GP (a) and GT (b) supernatants after $2 \mathrm{~h}$ incubation. For abbreviations and statistical analysis see Figure 1. (a) ${ }^{*} P<0.05$ CTR T1 versus CTR T2; ${ }^{*} P<0.05100 \mathrm{mg} / \mathrm{kg} \mathrm{T} 1$ versus $100 \mathrm{mg} / \mathrm{kg} \mathrm{T2} ;{ }^{*} P<0.05200 \mathrm{mg} / \mathrm{kg} \mathrm{T1}$ versus $200 \mathrm{mg} / \mathrm{kg} \mathrm{T} 2 .(\mathrm{b})$ ${ }^{*} P<0.05$ CTR T1 versus CTR T2; ${ }^{*} P<0.05$ CTR T1 versus $200 \mathrm{mg} / \mathrm{kg} \mathrm{T1} ;{ }^{\S} \mathrm{P}<0.001100 \mathrm{mg} / \mathrm{kg}$ T1 versus $100 \mathrm{mg} / \mathrm{kg}$ T2; ${ }^{\S} P<0.001$ $100 \mathrm{mg} / \mathrm{kg}$ T1 versus $200 \mathrm{mg} / \mathrm{kg}$ T1.

of untreated samples were higher in comparison to $200 \mathrm{mg} / \mathrm{kg}$ treated samples at $\mathrm{T} 1$ (data not shown).

In GT supernatants, no differences in terms of IL-1 $\beta$ concentrations were noted in all samples (data not shown).

Values of spleen IL-1 $\beta$ production were not statistically significant in all samples (data not shown).

In GP supernatants, IL-6 amounts were significantly lower at $\mathrm{T} 2$ versus $\mathrm{T} 1$ in all samples considered (Figure 4(a)).
However, IL-6 values of treated samples were not significantly different when compared to controls.

In GT supernatants, the same pattern of response was observed in terms of a significant reduction of T2 versus T1 values in all samples (Figure 4(b)).

Spleen IL-6 levels in untreated and treated samples were significantly higher at $\mathrm{T} 1$ versus $\mathrm{T} 2$. In the spleen, $\mathrm{T} 1$ values of IL-6 with $200 \mathrm{mg} / \mathrm{Kg}$ were lower than the respective untreated counterpart (Figure 4(c)). 


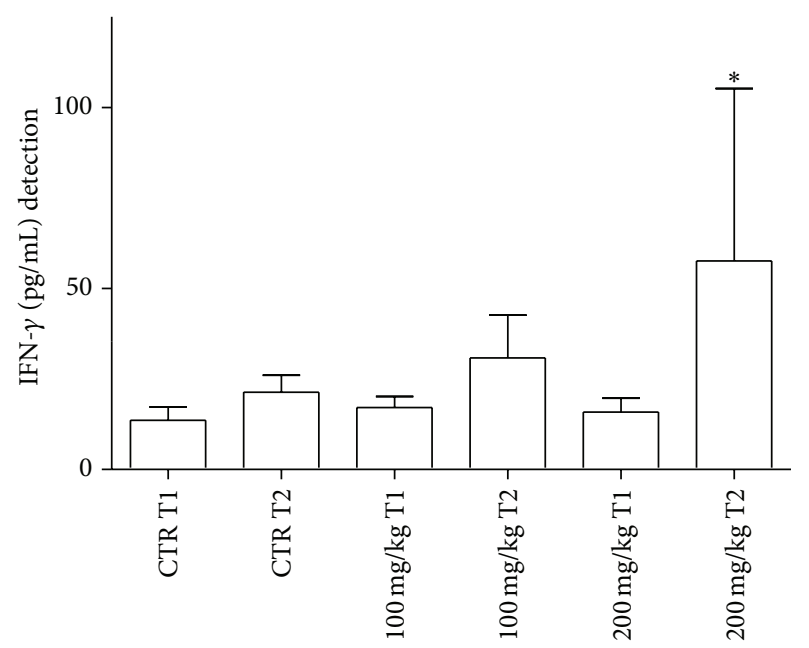

(a)

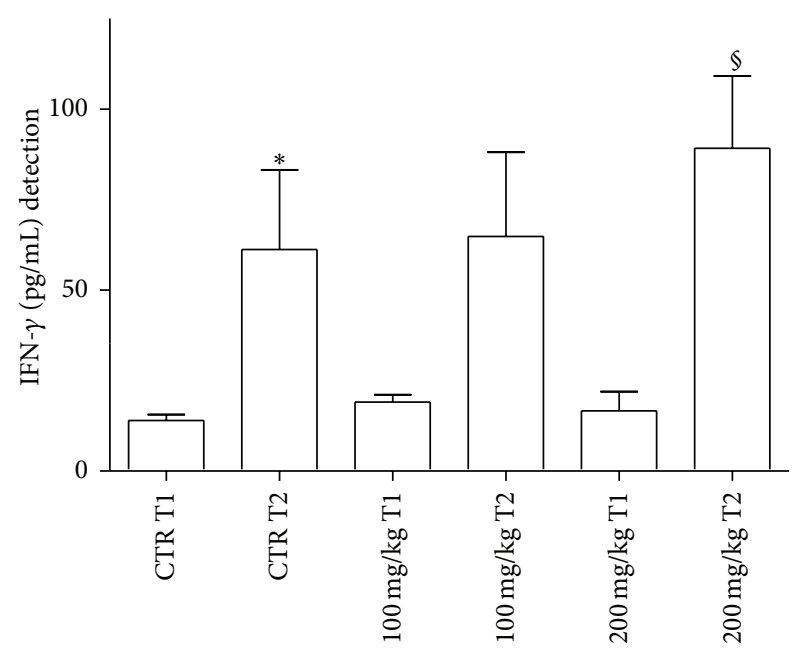

(b)

Figure 3: IFN- $\gamma$ levels released from GT (a) and spleen (b) supernatants after $2 \mathrm{~h}$ incubation. For abbreviations and statistical analysis see Figure 1. (a) ${ }^{*} P<0.05200 \mathrm{mg} / \mathrm{kg}$ T1 versus $200 \mathrm{mg} / \mathrm{kg}$ T2. (b) ${ }^{*} P<0.05$ CTR T1 versus CTR T2; ${ }^{\S} P<0.01200 \mathrm{mg} / \mathrm{kg}$ T1 versus $200 \mathrm{mg} / \mathrm{kg}$ T2.

In GP supernatants, IFN- $\gamma$ production was basically the same in all samples (data not shown).

In GT treated samples with $200 \mathrm{mg} / \mathrm{kg}$ dose a significant increase in IFN- $\gamma$ secretion was detected in comparison to all samples, except for T2 controls (Figure 5(a)).

At T2, spleen IFN- $\gamma$ release significantly increased in treated samples in comparison to the remaining samples. In addition, at T2, values were higher with $200 \mathrm{mg} / \mathrm{kg}$ dose in comparison to $100 \mathrm{mg} / \mathrm{kg}$ dose. (Figure 5(b)).

3.1. Basic Histology and Histochemistry. The histological appearance of spleen, stained with H\&E, is shown in Figure 6(a).

These images show an outer capsule, pink stained, consisting of connective tissue and small trabeculae extended into the parenchyma, which can be divided into a red and white pulp, respectively. However, this arrangement is not in an orderly manner, as can be observed in spleen of higher vertebrates since the two types of tissue are always intermixed. Anyway, the red pulp consists of a reticular cell network supporting blood-filled sinusoids that hold diverse cell population, including $\mathrm{M} \varnothing$ and lymphocytes, while the white pulp is composed of small spherical corpuscles also called "ellipsoids" [4], MØ free, and MMCs. Splenic ellipsoids are divided into arterioles forming dense-walled capillaries that are capable of collecting enormous quantities of small particulate antigens. MØ and MMCs exhibit irregular boundaries with densely filled cytoplasmic granules and other unidentified substances. Of note, it becomes difficult to distinguish the nucleus from the rest of the cytoplasm. For this reason, they were cytochemically identified with Perox and Anae staining (Figure 6(b)). The presence of ferric iron and lipofuscin-ceroids in MMCs was detected as dark brown granules with Mallory and Perls-Van Gieson staining, respectively (Figures 6(c) and 6(d)).
3.2. Quantitative Analyses of MMC. The size of MMCs varied greatly within the same section; some formed large clusters measuring up to $77 \mu \mathrm{m}$ in area, while others were smaller, less than $20 \mu \mathrm{m}$, likely monocellular $\mathrm{M} \varnothing$. The single size of $\mathrm{M} \varnothing$ and MMCs did not significantly differ between groups. Instead, number and sum of surfaces occupied by $\mathrm{M} \varnothing$ and MMC were different in spleen samples from all farmed fish at $\mathrm{T} 1$ and at $\mathrm{T} 2$, respectively.

$\mathrm{M} \varnothing$ percentage was higher in controls than that observed in treated fish at $\mathrm{T} 1$ with both polyphenol doses.

MMC percentage was lower in controls than that detected in treated fish with $200 \mathrm{mg} / \mathrm{kg}$ dose.

At T2, MMC percentage significantly increased with both concentrations of polyphenols in comparison to untreated fish (Figure 7).

At T1 and T2, the area occupied by control M $\varnothing$ decreased compared to treated fish. On the contrary, the area occupied by MMCs increased in polyphenol-administered fish. In particular, $\mathrm{M} \varnothing$ areas showed no statistical difference in controls versus treated fish at $\mathrm{T} 1$ and at T2. Instead, MMC areas were higher in treated fish when compared to controls at T2 with both polyphenol concentrations (Figure 8).

\section{Discussion}

Polyphenols are endowed with antioxidant and anti-inflamma-tory activities as documented by a series of data obtained in animals and humans [55-59]. Stemming from the concept that farmed fish are exposed to a continuous antigenic pressure owing to intensive rearing conditions in aquaculture, a robust stimulation of their immune system likely takes place. In principle, microbial challenges along with environmental insults (e.g., ultraviolet radiation) may trigger an early protective immune response in fish which may be converted into a chronic inflammation in the presence 


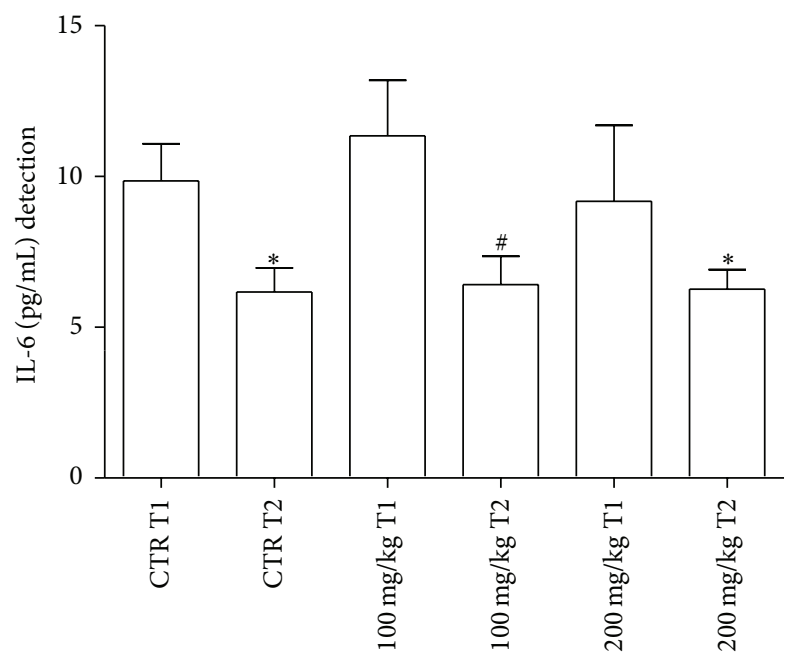

(a)

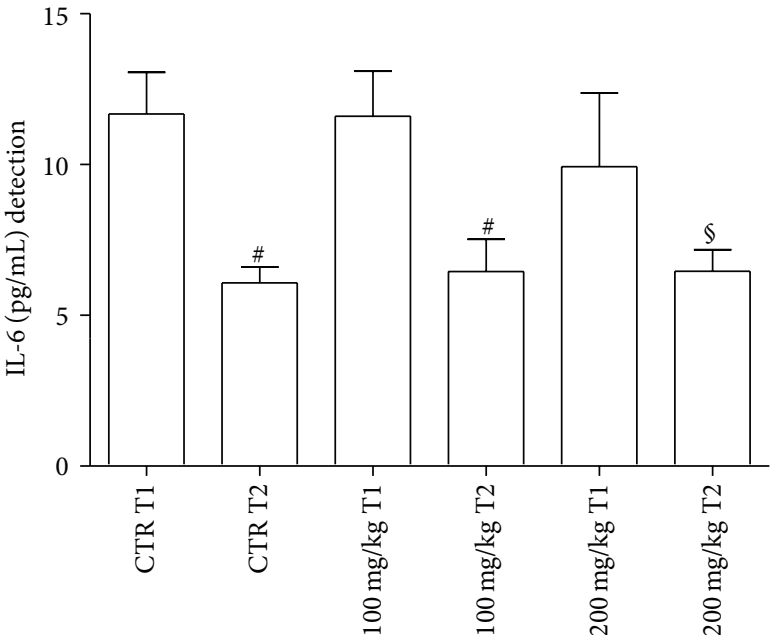

(b)

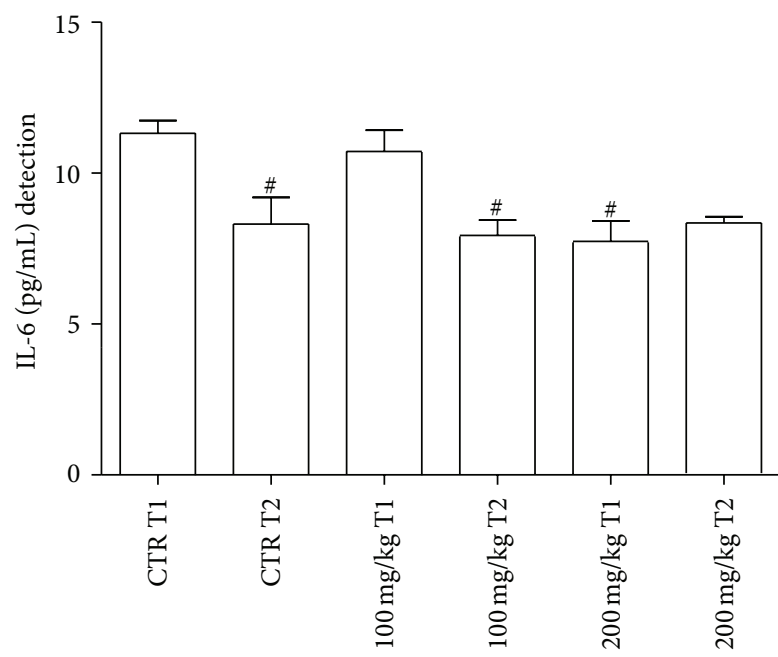

(c)

FIGURE 4: IL-6 levels released from GP (a), GT (b), and spleen (c) supernatants after $24 \mathrm{~h}$ incubation. For abbreviations and statistical analysis see Figure 1. (a) ${ }^{*} P<0.05$ CTR T1 versus CTR T2; ${ }^{\S} P<0.01200 \mathrm{mg} / \mathrm{kg}$ T1 versus $200 \mathrm{mg} / \mathrm{kg}$ T2. (b) ${ }^{*} P<0.0001 \mathrm{CTR}$ T1 versus CTR T2; ${ }^{\#} P<0.0001100 \mathrm{mg} / \mathrm{kg} \mathrm{T} 1$ versus $100 \mathrm{mg} / \mathrm{kg} \mathrm{T} 2 ;{ }^{\circledR} P<0.01200 \mathrm{mg} / \mathrm{kg} \mathrm{T} 1$ versus $200 \mathrm{mg} / \mathrm{kg} \mathrm{T2}$. (c) ${ }^{\#} P<0.0001 \mathrm{CTR}$ T1 versus CTR T2; ${ }^{\#} P<0.0001$ CTR T1 versus $200 \mathrm{mg} / \mathrm{kg} \mathrm{T1} ;{ }^{\#} P<0.0001100 \mathrm{mg} / \mathrm{kg}$ T1 versus $100 \mathrm{mg} / \mathrm{kg} \mathrm{T2} ;{ }^{\#} P<0.0001100 \mathrm{mg} / \mathrm{kg} \mathrm{T} 1 \mathrm{versus} 200 \mathrm{mg} / \mathrm{kg} \mathrm{T1}$.

of a persistent immune stimulation [60, 61]. Ultimately, this pathological condition may increase fish mortality in aquaculture and/or lower quality of meat in terms of dietary consumption.

In the light of these considerations, we have treated farmed sea bass with a polyphenol-enriched feed in order to evaluate putative modifications of intestinal and splenic immune responses.

Release of cytokines from gut and spleen of treated and untreated fish has been evaluated under conditions of short term $(2 \mathrm{~h})$ or long term culture $(24 \mathrm{~h})$. In fact, previously, it has been demonstrated that production of fish cytokines is different according to length of incubation time of immune cells [62].

With regard to IL-1 $\beta$ concentrations, this cytokine decreases in treated samples in GP in comparison to controls after $2 \mathrm{~h}$ of incubation. In the spleen, no significant differences are observed between conventionally fed and polyphenol fed animals. It is well known that IL- $1 \beta$ is a proinflammatory cytokine characterized by the functional conservation of its signaling between mammalian and teleost lineages [63]. In principle, IL-1 $\beta$ protects the host against potential pathogens, while generating a detrimental inflammatory milieu in the case of its exaggerated production in response to persistent stimuli. As demonstrated by in vitro studies with sea bass, in head kidney leukocytes stimulated with Vagococcus fluvialis L-21 upregulation of IL-1 $\beta$ and Tumor Necrosis Factor (TNF)- $\alpha$ suggests an early inflammatory response [64]. This has also been confirmed by experiments in zebrafish following tissue injury [65]. In our experimental model, IL-1 $\beta$ reduction in treated samples seems to correlate with less fish mortality and reduced frequency of infections 


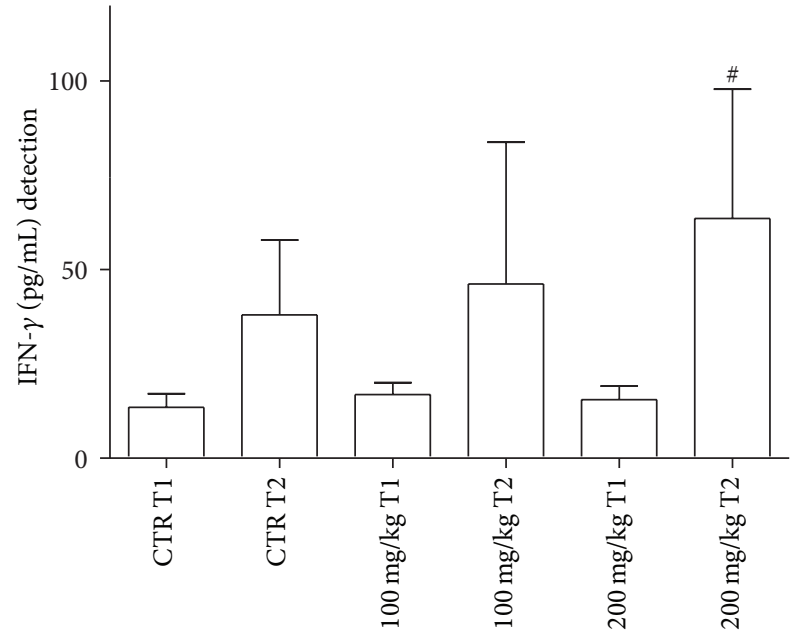

(a)

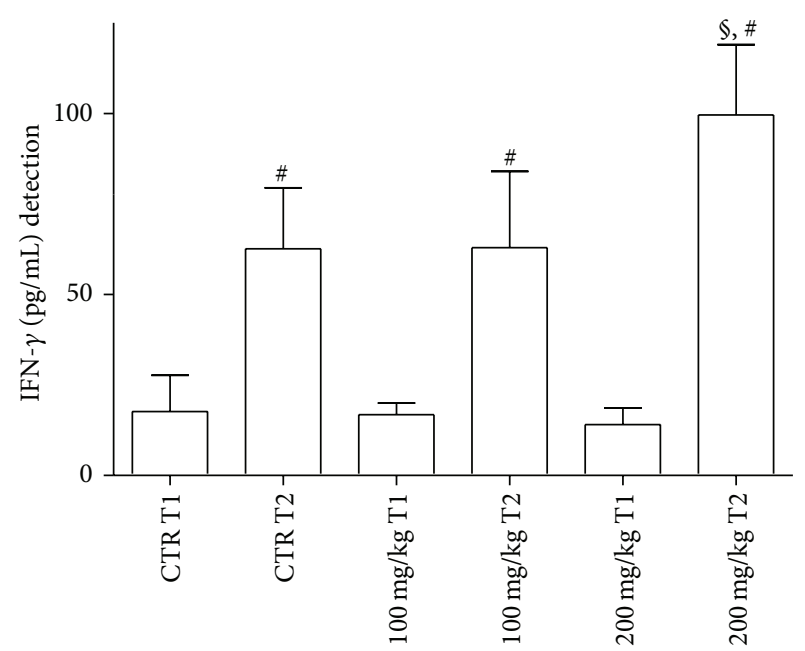

(b)

Figure 5: IFN- $\gamma$ levels released from GT (a) and spleen (b) supernatants after $24 \mathrm{~h}$ incubation. For abbreviations and statistical analysis see Figure 1. (a) ${ }^{\#} P<0.0001200 \mathrm{mg} / \mathrm{kg}$ T1 versus $200 \mathrm{mg} / \mathrm{kg}$ T2; (b) ${ }^{\#} P<0.0001 \mathrm{CTR}$ T1 versus CTR T2; ${ }^{\S} P<0.01 \mathrm{CTR}$ T2 versus $200 \mathrm{mg} / \mathrm{kg}$ T2; ${ }^{\#} P<0.0001100 \mathrm{mg} / \mathrm{kg}$ T1 versus $100 \mathrm{mg} / \mathrm{kg} \mathrm{T} 2 ;{ }^{\S} P<0.01100 \mathrm{mg} / \mathrm{kg}$ T2 versus $200 \mathrm{mg} / \mathrm{kg} \mathrm{T2} ;{ }^{\#} P<0.0001200 \mathrm{mg} / \mathrm{kg} \mathrm{T1} \mathrm{versus} 200 \mathrm{mg} / \mathrm{kg}$ $\mathrm{T} 2$.

(manuscript in preparation), thus indicating a potential beneficial effect exerted by polyphenols. Quite interestingly, in our fish samples production of splenic IL- $1 \beta$ is much less than that observed in the intestines, thus suggesting a more effective capacity of spleen phagocytes to effectively destroy pathogens, thus leading to their immediate clearance. Instead, in the intestines the reduced contingent of $\mathrm{M} \varnothing$ as well as lymphocytes, as documented by Figure 9(b), may lead to pathogen persistence with a continuous triggering of IL- $1 \beta$ release.

In mammals, IL-6 is an acute phase reactant which is also involved in hematopoiesis, inflammation, and immunomodulation, even including antibody production [66]. In fish, scarce information is available on the function of IL- 6 despite the recent identification of its gene. In addition, IL- 6 induced expression by IL- $1 \beta$ remains to be clarified in fish [67]. In our test system, decreases of IL- 6 values occur in the GT (at $\mathrm{T} 1$ with $200 \mathrm{mg} / \mathrm{kg}$ dose $/ 2 \mathrm{~h}$ ) and in the spleen (at T1 with $200 \mathrm{mg} / \mathrm{kg} / 24 \mathrm{~h})$.

With regard to IFN- $\gamma$ production, it is well known that this cytokine, mainly released by $\mathrm{T}$ helper (h)-1 cells and Th1like cells $[68,69]$, is highly protective for the host against intracellular bacterial and viral infections. In our experiments, IFN- $\gamma$ mostly increases in the spleen under the influence of polyphenols, thus indicating a more predominant immune adaptive function exerted by this lymphoid organ in comparison to the gut. Quite interestingly, in Atlantic halibut, experimentally infected with nodavirus, increased levels of $\mathrm{T}$ cell marker and IFN- $\gamma$ transcripts have been observed as an example of a robust adaptive immune response. In the same context, in vitro experiments have also shown the intervention of IL- 6 and IFN- $\gamma$ with involvement of CD $8 \beta+$ cells against nodavirus [70]. Furthermore, Jung and associates [71] have reported that recombinant IFN- $\gamma$ protects the olive flounder (Paralichthys olivaceus) against Edwardsiella (E.) tarda, thus increasing survival in comparison to E. tarda treated group only.

In relevance to polyphenols used in our experiments, green tea administration [72] to rainbow trout (Oncorhynchus mykiss) was able to modulate immune-related gene expression of several cytokines, such as IL- $1 \beta$, IL-6, IL-8, and IL10 and TNF- $\alpha$ in spleen, liver, and kidney. In general terms, upregulation of all cytokines was observed except for the reduction of IL-10. Furthermore, an enhancement of the antioxidant system was demonstrated in green tea treated animals.

Finally, as far as polyphenol doses used in our feeds are concerned, no differences have been evidenced between 100 and $200 \mathrm{mg} / \mathrm{kg}$ concentrations used.

Fish MMCs are considered as an expression of primitive cellular aggregates where $\mathrm{M} \varnothing$ engulf various pigments and cell debris but also exert an early protection against pathogens [16-18]. The analysis of MØ and MMCs demonstrates that treatment with polyphenols induces an increase of MMC numbers and related areas. This means that $\mathrm{M} \varnothing$ may form clusters which generate MMCs which, in turn, may afford more protection to fish against pathogens, even including viruses. In fact, we can hypothesize that all trapped material is first engulfed by $\mathrm{M} \varnothing$ and then transported to MMCs for their processing. Of note, it is possible to observe MMCs mainly located in close proximity of blood vessels. Reduction in $\mathrm{M} \varnothing$ number by effect of polyphenols may explain the decrease of IL-1 $\beta$ while it is conceivable that MMCs may act as antigen presenting cells toward $\mathrm{T}$ lymphocytes, which in turn release IFN- $\gamma$. Therefore, increase in MMCs seems to contribute to less mortality and reduction of infectious events in farmed sea bass.

In conclusion, our results confirm and extend previous data related to the anti-inflammatory and immunemodulating activities exerted by polyphenols [45, 48, 59]. 


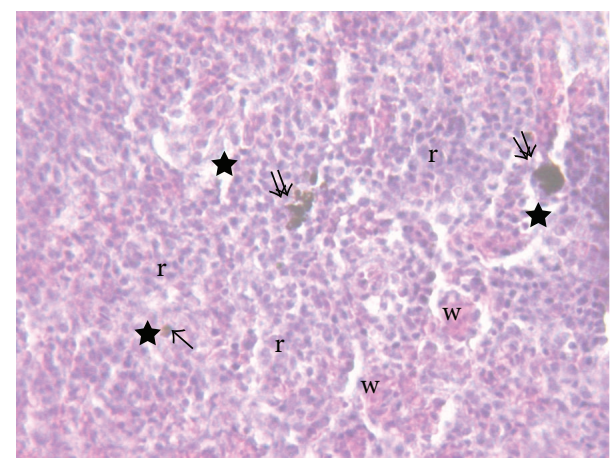

(a)

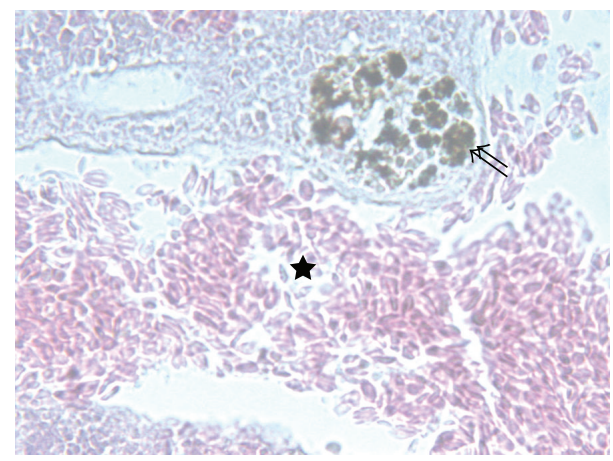

(c)

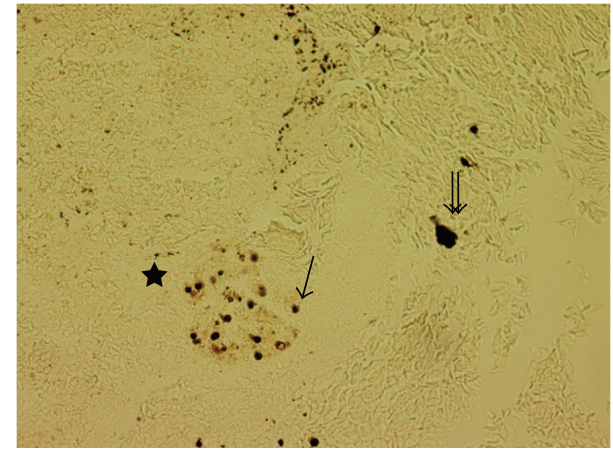

(b)

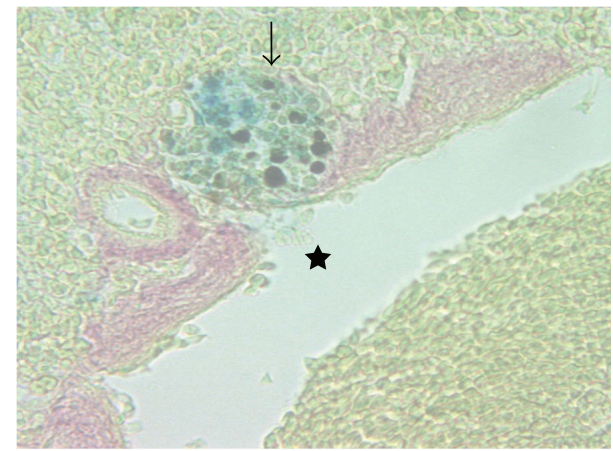

(d)

Figure 6: (a) Splenic tissue of Dicentrarchus labrax L. organized in areas of red pulp (r) and white pulp (w); the last consisting of ellipsoids, MØ (arrow), and MMC (double arrow) (H\&E, 100x). ((b), (c), (d)) At higher magnification (400x) MØ and MMC appear distributed above all near vessels (star) (Anae, Mallory, and Perls-Van Gieson, resp.).

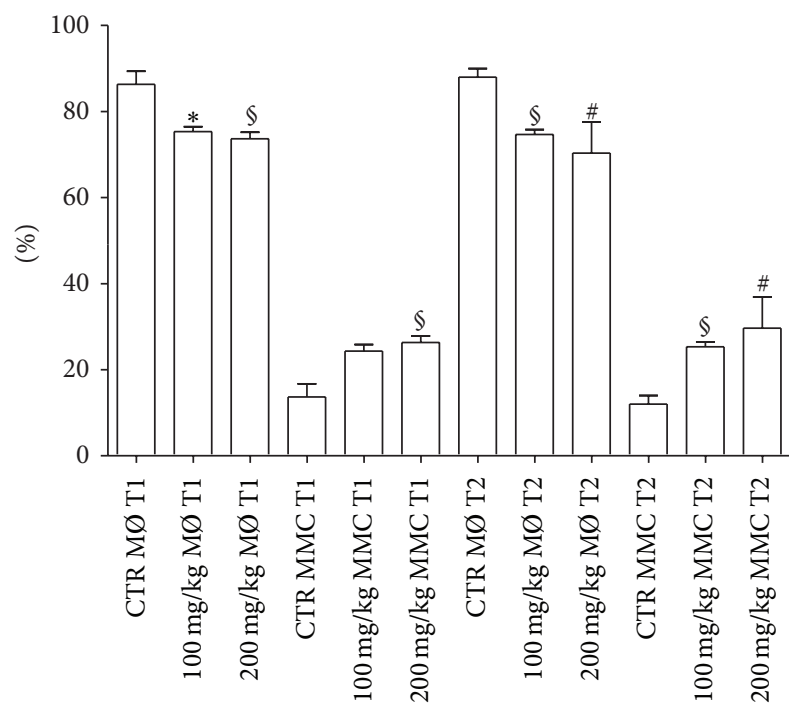

FIGURE 7: Spleen number percentages of MØ and MMCs from treated and untreated fish. For abbreviations and statistical analysis see Figure $1 .{ }^{*} P<0.05 \mathrm{CTR}$ MØ T1 versus $100 \mathrm{mg} / \mathrm{kg} \mathrm{M} \varnothing \mathrm{T} 1$; ${ }^{\S} \mathrm{P}<0.01 \mathrm{CTR} \mathrm{M} \varnothing \mathrm{T} 1$ versus $200 \mathrm{mg} / \mathrm{kg} \mathrm{M \emptyset} \mathrm{T1;}{ }^{\circledR} \mathrm{P}<0.01 \mathrm{CTR}$ MMC T1 versus $200 \mathrm{mg} / \mathrm{kg}$ MMC T1; ${ }^{\circledR} P<0.01$ CTR MØ T2 versus $100 \mathrm{mg} / \mathrm{kg}$ МØ T2; ${ }^{*} P<0.0001$ CTR MØ T2 versus $200 \mathrm{mg} / \mathrm{kg}$ MØ T2; ${ }^{\circledR} P<0.01$ CTR MMC T2 versus $100 \mathrm{mg} / \mathrm{kg}$ MMC T2; ${ }^{\#} P<0.0001$ CTR MMC T2 versus $200 \mathrm{mg} / \mathrm{kg}$ MMC T2.

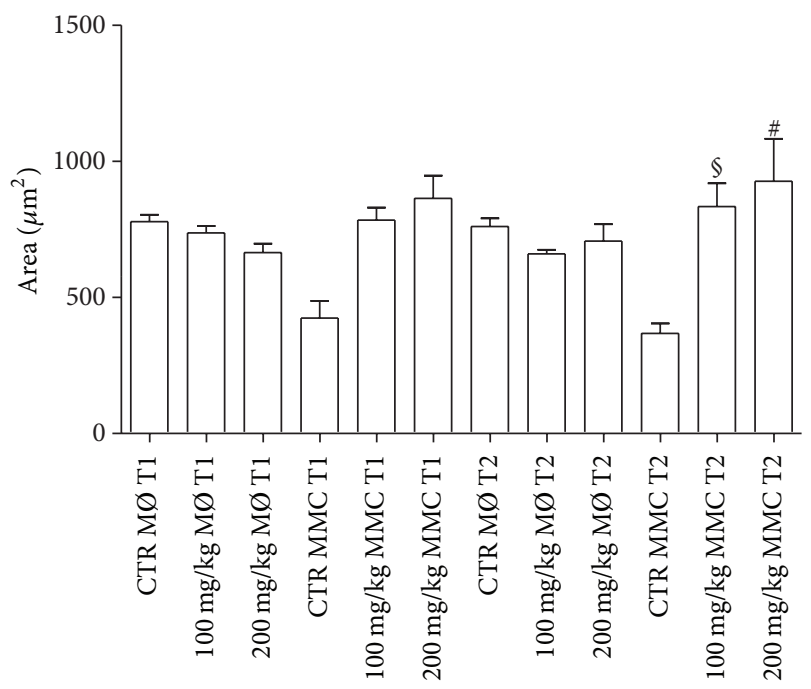

FIGURE 8: Spleen areas occupied by MØ and MMCs of treated and untreated fish. For abbreviations and statistical analysis see Figure 1. ${ }^{\S} P<0.01$ CTR MMC T2 versus $100 \mathrm{mg} / \mathrm{kg} \mathrm{T2} ;{ }^{*} P<0.0001 \mathrm{CTR}$ MMC T2 versus $200 \mathrm{mg} / \mathrm{kg}$ T2.

This contention is supported by the reduction of IL- $1 \beta$ and IL6 concentrations and enhancement of spleen IFN- $\gamma$ release. This dietary approach may be exploitable by farmed fish 


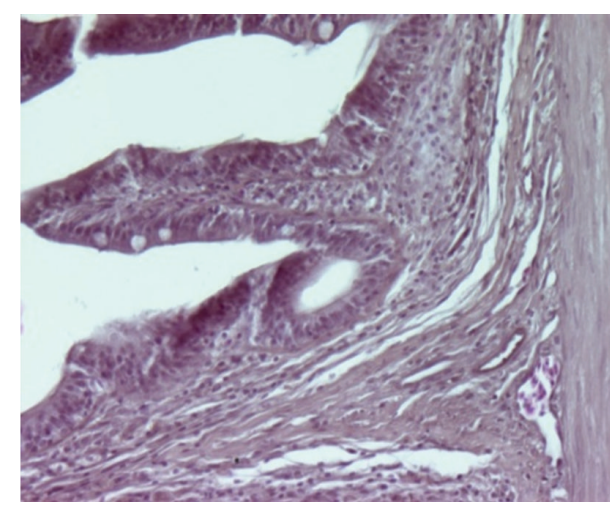

(a)

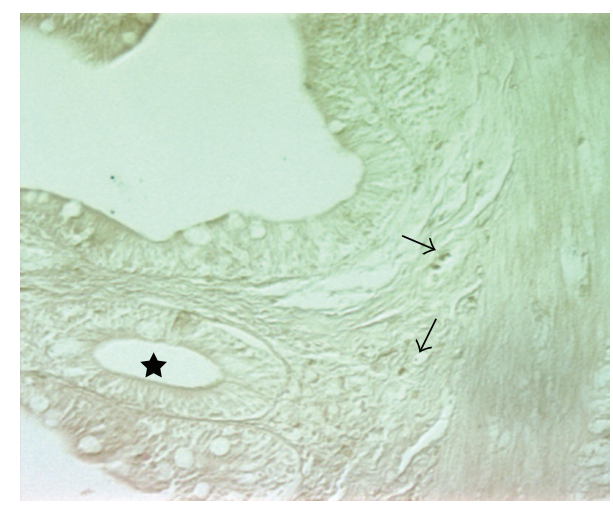

(b)

FigURE 9: Intestinal sections from farmed sea bass. (a) (H\&E staining, 250x) provides a general view of the gut. In (b) (Anae staining, 250x) a few lymphocytes (upper arrows) and one $\mathrm{M} \varnothing$ (lower arrow) are evident in the lamina propria. Some blood vessels are present in the section (see star).

companies in terms of either longer fish survival or more beneficial effect for consumers owing to higher quality of meat.

\section{Conflict of Interests}

The authors declare that they have no competing interests.

\section{Acknowledgment}

This paper was supported by Regione Puglia-Project Vis Maris (Bando FESR 2007-13-Azione 1.2.4 Bando "Aiuti a Sostegno dei Partenariati Regionali per l'Innovazione").

\section{References}

[1] A. E. Ellis and M. De Sousa, "Phylogeny of the lymphoid system. I. A study of the fate of circulating lymphocytes in plaice," European Journal of Immunology, vol. 4, no. 5, pp. 338-343, 1974.

[2] E. O. Koppang, U. Fischer, L. Moore et al., "Salmonid T cells assemble in the thymus, spleen and in novel interbranchial lymphoid tissue," Journal of Anatomy, vol. 217, no. 6, pp. 728739, 2010.

[3] V. Micale and F. Perdichizzi, "A quantitative and histochemical study on melano-macrophage centres in the spleen of the teleost fish Diplodus annularis L.", Journal of Fish Biology, vol. 37, no. 2, pp. 191-197, 1990.

[4] C. M. Press, "Immunology of fishes", in Handbook of Vertebrate Immunology, P. P. Pastoret, P. Griegel, H. Bazin, and A. Govaerts, Eds., pp. 3-62, Academic Press, San Diego, Calif, USA, 1998.

[5] B. Kurtovic, E. Teskeredžic, and Z. Teskeredžic, "Histological comparison of spleen and kidney tissue from farmed and wild European sea bass (Dicentrarchus labrax L.)," Acta Adriatica, vol. 49, no. 2, pp. 147-154, 2008.

[6] M. Sundaresan, "Ultrastructure of spleen in the freshwater fish, Tilapia mossambica (Peters)," European Academic Research, vol. 2, no. 2, pp. 2894-2908, 2014.

[7] R. E. Wolke, "Piscine macrophage aggregates: a review," Annual Review of Fish Diseases, vol. 2, pp. 91-108, 1992.
[8] F. A. Vigliano, R. Bermúdez, M. I. Quiroga, and J. M. Nieto, "Evidence for melano-macrophage centres of teleost as evolutionary precursors of germinal centres of higher vertebrates: an immunohistochemical study," Fish and Shellfish Immunology, vol. 21, no. 4, pp. 467-471, 2006.

[9] C. M. Couillard, P. J. Williams, S. C. Courtenay, and G. P. Rawn, "Histopathological evaluation of Atlantic tomcod (Microgadus tomcod) collected at estuarine sites receiving pulp and paper mill effluent," Aquatic Toxicology, vol. 44, no. 4, pp. 263-278, 1999.

[10] C. Agius and R. J. Roberts, "Melano-macrophage centres and their role in fish pathology," Journal of Fish Diseases, vol. 26, no. 9, pp. 499-509, 2003.

[11] M. P. Herráez and A. G. Zapata, "Structural characterization of the melano-macrophage centres (MMC) of goldfish Carassius auratus," European Journal of Morphology, vol. 29, no. 2, pp. 89102, 1991.

[12] M. G. Taylor and K. Simkiss, "Structural and analytical studies on metal ion-containing granules," in Biomineralization and Biochemical Perspectives, S. Mann, R. J. Webb, and R. J. P. Williams, Eds., pp. 427-460, VHC Publishers, Weinheim, Germany, 1989.

[13] J. D. Corrêa Junior, S. Allodi, and M. Farina, "Enzymatic, analytical and structural aspects of electron-dense granules in cells of Ucides cordatus (Crustacea, Decapoda) hepatopancreas," Cell and Tissue Research, vol. 311, no. 1, pp. 107-116, 2003.

[14] J. D. Corrêa Jr., M. I. Bruno, S. Allodi, and M. Farina, "Effects of $\mathrm{H}^{+}$concentration on amorphous mineral granules: structural stability and elemental mobilization," Journal of Structural Biology, vol. 166, no. 1, pp. 59-66, 2009.

[15] N. Suresh, "Effect of cadmium chloride on liver, spleen and kidney melano macrophage centres in Tilapia mossambica," Journal of Environmental Biology, vol. 30, no. 4, pp. 505-508, 2009.

[16] R. J. Roberts, "Melanin containing cells of teleost fish and their relation to disease," in Fish Pathology, W. E. Ribelin and G. Migaki, Eds., pp. 399-428, University of Wisconsin Press, Madison, Wis, USA, 1975.

[17] J. D. Borucinska, K. Kotran, M. Shackett, and T. Barker, "Melanomacrophages in three species of free-ranging sharks from the northwestern Atlantic, the blue shark Prionacae glauca 
(L.), the shortfin mako, Isurus oxyrhinchus Rafinesque, and the thresher, Alopias vulpinus (Bonnaterre)," Journal of Fish Diseases, vol. 32, no. 10, pp. 883-891, 2009.

[18] H. Kranz and N. Peters, "Melano-macrophage centres in liver and spleen of ruffe (Gymnocephalus cernua) from the Elbe Estuary," Helgoländer Meeresuntersuchungen, vol. 37, no. 1-4, pp. 415-424, 1984.

[19] L. Passantino, A. Cianciotta, F. Jirillo, M. Carrassi, E. Jirillo, and G. F. Passantino, "Lymphoreticular system in fish: erythrocytemediated immunomodulation of macrophages contributes to the formation of melanomacrophage centers," Immunopharmacology and Immunotoxicology, vol. 27, no. 1, pp. 147-161, 2005.

[20] C. L. Brown and C. J. George, "Age-dependent accumulation of macrophage aggregates in the yellow perch, Perca flavescens (Mitchill)," Journal of Fish Diseases, vol. 8, no. 1, pp. 135-138, 1985.

[21] V. S. Blazer, R. E. Wolke, J. Brown, and C. A. Powell, "Piscine macrophage aggregate parameters as health monitors: effect of age, sex, relative weight, season and site quality in largemouth bass (Micropterus salmoides)," Aquatic Toxicology, vol. 10, no. 4, pp. 199-215, 1987.

[22] A. L. Pulsford, K. P. Ryan, and J. A. Nott, "Metals and melanomacrophages in flounder, Platichthys flesus, spleen and kidney," Journal of the Marine Biological Association of the United Kingdom, vol. 72, no. 2, pp. 483-498, 1992.

[23] A. N. Tchernitchin, W. Carter, J. Soto, and P. Baumann, "Effect of eosinophil-degranulating estrogens on spleen eosinophils and white pulp/red pulp ratio," Agents and Actions, vol. 31, no. 3-4, pp. 249-256, 1990.

[24] K. Rebok, M. Jordanova, and I. Tavciovska-Vasileva, "Spleen histology in the female ohrid trout, Salmo letnica (Kar.) (Teleostei, Salmonidae) during the reproductive cycle," Archives of Biological Sciences, vol. 63, no. 4, pp. 1023-1030, 2011.

[25] H. Kranz, "Changes in splenic melano-macrophage centres of dab Limanda limanda during and after infection with ulcer disease," Diseases of Aquatic Organisms, vol. 6, pp. 167-173, 1989.

[26] A. Haaparanta, E. T. Valtonen, R. Hoffmann, and J. Holmes, "Do macrophage centres in freshwater fishes reflect the differences in water quality?" Aquatic Toxicology, vol. 34, no. 3, pp. 253-272, 1996.

[27] D. Montero, V. S. Blazer, J. Socorro, M. S. Izquierdo, and L. Tort, "Dietary and culture influences on macrophage aggregate parameters in gilthead seabream (Sparus aurata) juveniles," Aquaculture, vol. 179, no. 1-4, pp. 523-534, 1999.

[28] M. M. A. Mahmoud, O. E. Kilany, and A. A. Dessouki, "Effects of fish meal replacement with soybean meal and use of exogenous enzymes in diets of Nile tilapia (Oreochromisniloticus) on growth, feed utilization, histopathological changes and blood parameters," Life Science Journal, vol. 11, no. 2, article 2, pp. 6-18, 2014.

[29] A. Sitjà-Bobadilla, M. J. Redondo, R. Bermúdez et al., "Innate and adaptive immune responses of turbot, Scophthalmus maximus (L.), following experimental infection with Enteromyxum scophthalmi (Myxosporea: Myxozoa)," Fish and Shellfish Immunology, vol. 21, no. 5, pp. 485-500, 2006.

[30] H. J. Ribeiro, M. S. Procópio, J. M. M. Gomes et al., "Functional dissimilarity of melanomacrophage centres in the liver and spleen from females of the teleost fish Prochilodus argenteus," Cell and Tissue Research, vol. 346, no. 3, pp. 417-425, 2011.

[31] F. A. Vigliano, R. Bermúdez, M. I. Quiroga, and J. M. Nieto, "Evidence for melano-macrophage centres of teleost as evolutionary precursors of germinal centres of higher vertebrates: an immunohistochemical study," Fish \& Shellfish Immunology, vol. 21, no. 4, pp. 467-471, 2006.

[32] M. Espe, H. Sveier, I. Høgøy, and E. Lied, "Nutrient absorption and growth of Atlantic salmon (Salmo salar L.) fed fish protein concentrate," Aquaculture, vol. 174, no. 1-2, pp. 119-137, 1999.

[33] A. G. J. Tacon and M. Metian, "Feed matters: satisfying the feed demand of aquaculture," Reviews in Fisheries Science \& Aquaculture, vol. 23, no. 1, pp. 1-10, 2015.

[34] A. G. J. Tacon, "Feed ingredients for warm water fish. Fish meal and other processed feedstuffs," FAO Fisheries Circular, no. 856, p. $64,1993$.

[35] J. Raa, G. Rorstad, R. E. Engstad, and B. Robertson, “The use of immunostimulants to increase resistance of aquatic organism to microbial infections," in Disease in Asian Aquaculture. Proceedings of the First Symposium on Disease in Asian Aquaculture, M. Shariff, R. P. Subasingh, and J. R. Arthur, Eds., vol. 1, pp. 39-50, Asian Fisheries Society, Manila, Philippines, 1992.

[36] T. Magrone and E. Jirillo, "The interplay between the gut immune system and microbiota in health and disease: nutraceutical intervention for restoring intestinal homeostasis," Current Pharmaceutical Design, vol. 19, no. 7, pp. 1329-1342, 2013.

[37] T. Magrone and E. Jirillo, “The interaction between gut microbiota and age-related changes in immune function and inflammation," Immunity \& Ageing, vol. 10, no. 1, article 31, 2013.

[38] J. H. Landsberg, "Myxosporean infections in cultured tilapias in Israel," The Journal of Protozoology, vol. 32, no. 1, pp. 194-201, 1985.

[39] S. M. Sharifuzzaman and B. Austin, "Influence of probiotic feeding duration on disease resistance and immune parameters in rainbow trout," Fish \& Shellfish Immunology, vol. 27, no. 3, pp. 440-445, 2009.

[40] M. Reyes-Becerril, F. Ascencio-Valle, M. E. Macias, M. Maldonado, M. Rojas, and M. Á. Esteban, "Effects of marine silages enriched with Lactobacillus sakei 5-4 on haematoimmunological and growth response in Pacific red snapper (Lutjanus peru) exposed to Aeromonas veronii," Fish \& Shellfish Immunology, vol. 33, no. 4, pp. 984-992, 2012.

[41] R. H. Kalil, T. T. Saad, and Y. M. Elabd, "Evaluation of immunomodulatory effect of some probiotics on coltured Oreochromis niloticus," Journal of the Arabian Aquacolture Society, vol. 6, no. 2, pp. 139-154, 2011.

[42] V. Kiron, "Fish immune system and its nutritional modulation for preventive health care," Animal Feed Science and Technology, vol. 173, no. 1-2, pp. 111-133, 2012.

[43] E. J. Noga, Fish Disease, Diagnosis and Treatment, edited by E. J. Noga, Wiley-Blackwell, Ames, Iowa, USA, 2nd edition, 2010.

[44] R. R. Watson, V. R. Preedy, and S. Zibaldi, Eds., Polyphenols in Human Health and Disease, vol. 1-2, Elsevier, Academic Press, 2014.

[45] T. Magrone, Y. Kumazawa, and E. Jirillo, "Polyphenol-mediated beneficial effects in healthy status and disease with special reference to immune-based mechanisms," in Polyphenols in Human Health and Disease, R. R. Watson, V. R. Preedy, and S. Zibaldi, Eds., vol. 1, pp. 467-479, Elsevier, Academic Press, 2014.

[46] R. J. Williams, J. P. E. Spencer, and C. Rice-Evans, "Flavonoids: antioxidants or signalling molecules?" Free Radical Biology \& Medicine, vol. 36, no. 7, pp. 838-849, 2004.

[47] F. Virgili and M. Marino, "Regulation of cellular signals from nutritional molecules: a specific role for phytochemicals, beyond antioxidant activity," Free Radical Biology \& Medicine, vol. 45, no. 9, pp. 1205-1216, 2008. 
[48] T. Magrone and E. Jirillo, "Polyphenols from red wine are potent modulators of innate and adaptive immune responsiveness," The Proceedings of the Nutrition Society, vol. 69, no. 3, pp. 279285,2010

[49] G. Marzulli, T. Magrone, L. Vonghia et al., "Immunomodulating and anti-allergic effects of Negroamaro and Koshu Vitis vinifera fermented grape marc (FGM)," Current Pharmaceutical Design, vol. 20, no. 6, pp. 864-868, 2014.

[50] J. Leiro, J. A. Arranz, A. Paramá, M. F. Álvarez, and M. L. Sanmartín, "In vitro effects of the polyphenols resveratrol, mangiferin and (-)-epigallocatechin-3-gallate on the scuticociliate fish pathogen Philasterides dicentrarchi," Diseases of Aquatic Organisms, vol. 59, no. 2, pp. 171-174, 2004.

[51] A. Alesci, N. Cicero, A. Salvo et al., "Extracts deriving from olive mill waste water and their effects on the liver of the goldfish Carassius auratus fed with hypercholesterolemic diet," Natural Product Research, vol. 28, no. 17, pp. 1343-1349, 2014.

[52] M. Roselli, A. Lovece, C. Bruno et al., "Antioxidant activity of Uva di Troia Canosina: comparison of two extraction methods," Clinical Immunology, Endocrine \& Metabolic Drugs, vol. 2, pp. 15, 2015.

[53] J. D. Metcalfe and J. F. Craig, "Ethical justification for the use and treatment of fishes in research," Journal of Fish Biology, vol. 68, no. 1, pp. 1-2, 2006.

[54] F. Jirillo, G. Passantino, M. A. Massaro et al., "In vitro elicitation of intestinal immune responses in teleost fish: evidence for a type IV hypersensitivity reaction in rainbow trout," Immunopharmacology and Immunotoxicology, vol. 29, no. 1, pp. 69-80, 2007.

[55] V. V. Trichet, "Nutrition and immunity: an update," Aquaculture Research, vol. 41, no. 3, pp. 356-372, 2010.

[56] C.-F. Huang, S.-S. Lin, P.-H. Liao, S.-C. Young, and C.-C. Yang, "The immunopharmaceutical effects and mechanisms of herb medicine," Cellular \& Molecular Immunology, vol. 5, no. 1, pp. 23-31, 2008.

[57] E. Awad, W. J. Mitchell, and B. Austin, "Effect of dietary supplements on cytokine gene expression in rainbow trout, Oncorhynchus mykiss (Walbaum)," Journal of Fish Diseases, vol. 34, no. 8, pp. 629-634, 2011.

[58] E. C. Amar, V. Kiron, S. Satoh, and T. Watanabe, "Enhancement of innate immunity in rainbow trout (Oncorhynchus mykiss Walbaum) associated with dietary intake of carotenoids from natural products," Fish \& Shellfish Immunology, vol. 16, no. 4, pp. 527-537, 2004.

[59] T. Magrone, V. Pugliese, S. Fontana, and E. Jirillo, "Human use of Leucoselect Phytosome with special reference to inflammatory-allergic pathologies in frail elderly patients," Current Pharmaceutical Design, vol. 20, no. 6, pp. 1011-1019, 2014.

[60] T. J. Bowden, "Modulation of the immune system of fish by their environment," Fish \& Shellfish Immunology, vol. 25, no. 4, pp. 373-383, 2008.

[61] S. Banerjee and M. Leptin, "Systemic response to ultraviolet radiation involves induction of leukocytic il-1 $\beta$ and inflammation in zebrafish," Journal of Immunology, vol. 193, no. 3, pp. 1408-1415, 2014.

[62] A.-C. Øvergård, I. Nepstad, A. H. Nerland, and S. Patel, "Characterisation and expression analysis of the Atlantic halibut (Hippoglossus hippoglossus L.) cytokines: IL-1 $\beta$, IL-6, IL-11, IL$12 \beta$ and IFN $\gamma$," Molecular Biology Reports, vol. 39, no. 3, pp. 2201-2213, 2012.
[63] G. Beck and G. S. Habicht, "Primitive cytokines: harbingers of vertebrate defense," Immunology Today, vol. 12, no. 6, pp. 180183, 1991.

[64] L. Román, F. Real, D. Padilla et al., "Cytokine expression in head-kidney leucocytes of European sea bass (Dicentrarchus labrax L.) after incubation with the probiotic Vagococcus fluvialis L-21," Fish \& Shellfish Immunology, vol. 35, no. 4, pp. 13291332, 2013.

[65] N. V. Ogryzko, E. E. Hoggett, S. Solaymani-Kohal et al., "Zebrafish tissue injury causes upregulation of interleukin1 and caspase-dependent amplification of the inflammatory response," DMM Disease Models \& Mechanisms, vol. 7, no. 2, pp. 259-264, 2014.

[66] T. Hirano, "Interleukin 6 in autoimmune and inflammatory diseases: a personal memoir," Proceedings of the Japan Academy B: Physical and Biological Sciences, vol. 86, no. 7, pp. 717-730, 2010.

[67] D. B. Iliev, B. Castellana, S. Mackenzie, J. V. Planas, and F. W. Goetz, "Cloning and expression analysis of an IL-6 homolog in rainbow trout (Oncorhynchus mykiss)," Molecular Immunology, vol. 44, no. 7, pp. 1803-1807, 2007.

[68] B. Robertsen, "The interferon system of teleost fish," Fish \& Shellfish Immunology, vol. 20, no. 2, pp. 172-191, 2006.

[69] T. Magrone and E. Jirillo, “The interleukin-17/interleukin22 innate axis in the gut as a new drug target in allergicinflammatory and autoimmune diseases. A working hypothesis," Endocrine, Metabolic and Immune Disorders-Drug Targets, vol. 14, no. 2, pp. 145-151, 2014.

[70] A.-C. Øvergård, A. H. Nerland, I. U. Fiksdal, and S. Patel, "Atlantic halibut experimentally infected with nodavirus shows increased levels of T-cell marker and IFN $\gamma$ transcripts," Developmental and Comparative Immunology, vol. 37, no. 1, pp. 139-150, 2012.

[71] C. Y. Jung, J.-I. Hikima, M. Ohtani et al., "Recombinant interferon $\gamma$ activates immune responses against Edwardsiella tarda infection in the olive flounder, Paralichthys olivaceus," Fish \& Shellfish Immunology, vol. 33, no. 2, pp. 197-203, 2012.

[72] S. Nootash, N. Sheikhzadeh, B. Baradaran et al., "Green tea (Camellia sinensis) administration induces expression of immune relevant genes and biochemical parameters in rainbow trout (Oncorhynchus mykiss)," Fish and Shellish Immunology, vol. 35, no. 6, pp. 1916-1923, 2013. 


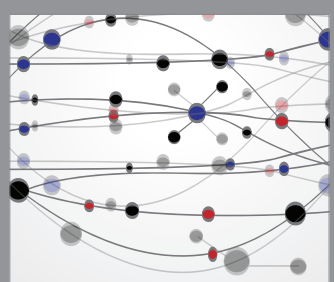

The Scientific World Journal
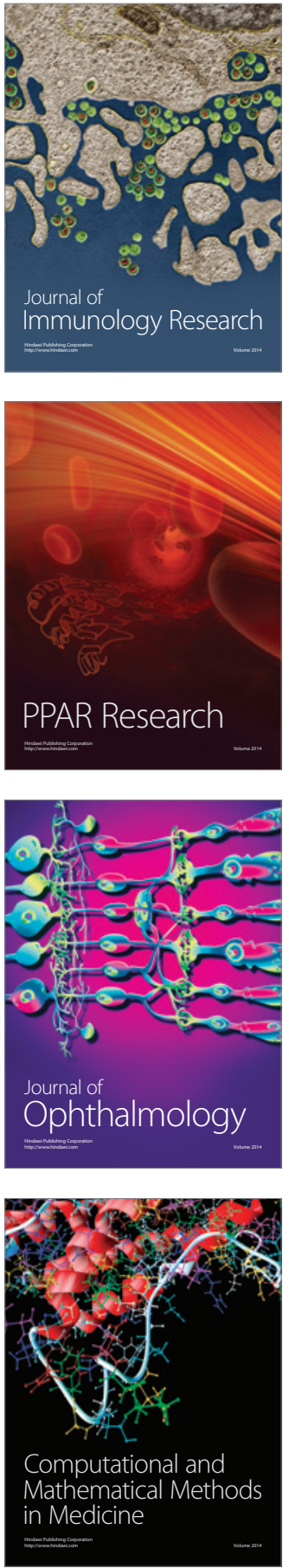

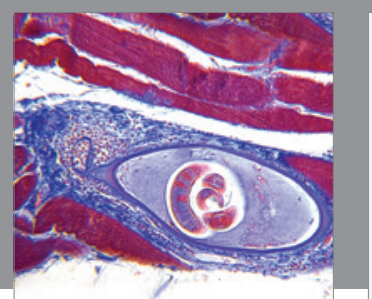

Gastroenterology Research and Practice

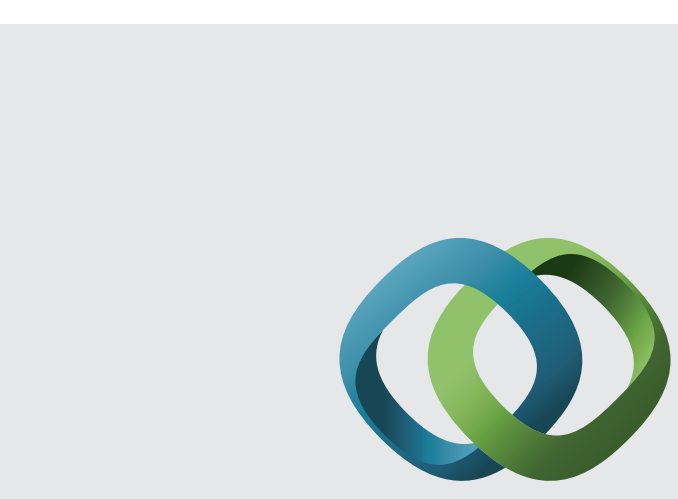

\section{Hindawi}

Submit your manuscripts at

http://www.hindawi.com
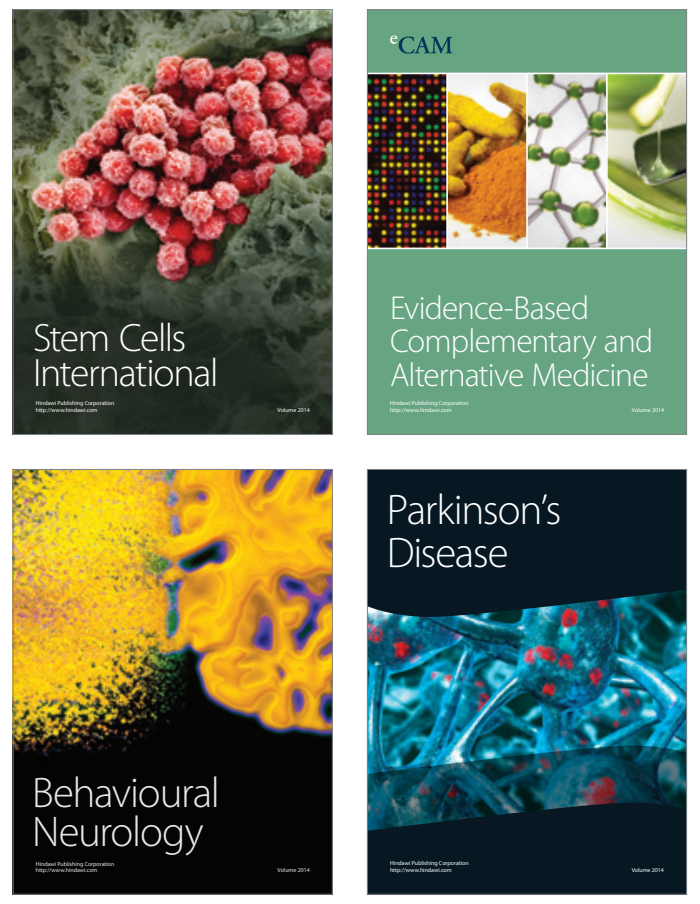
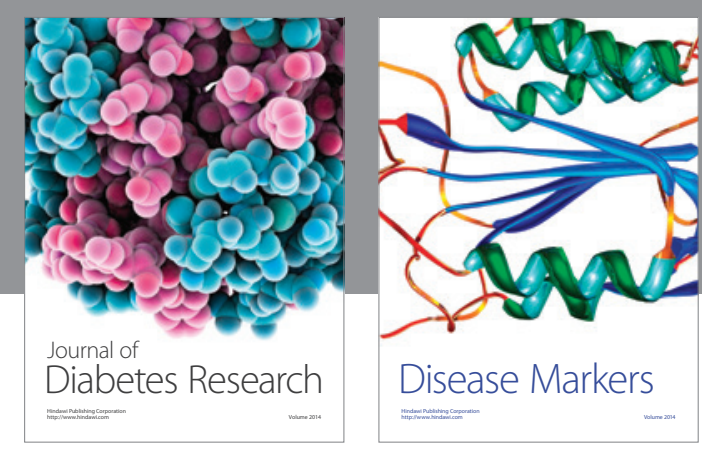

Disease Markers
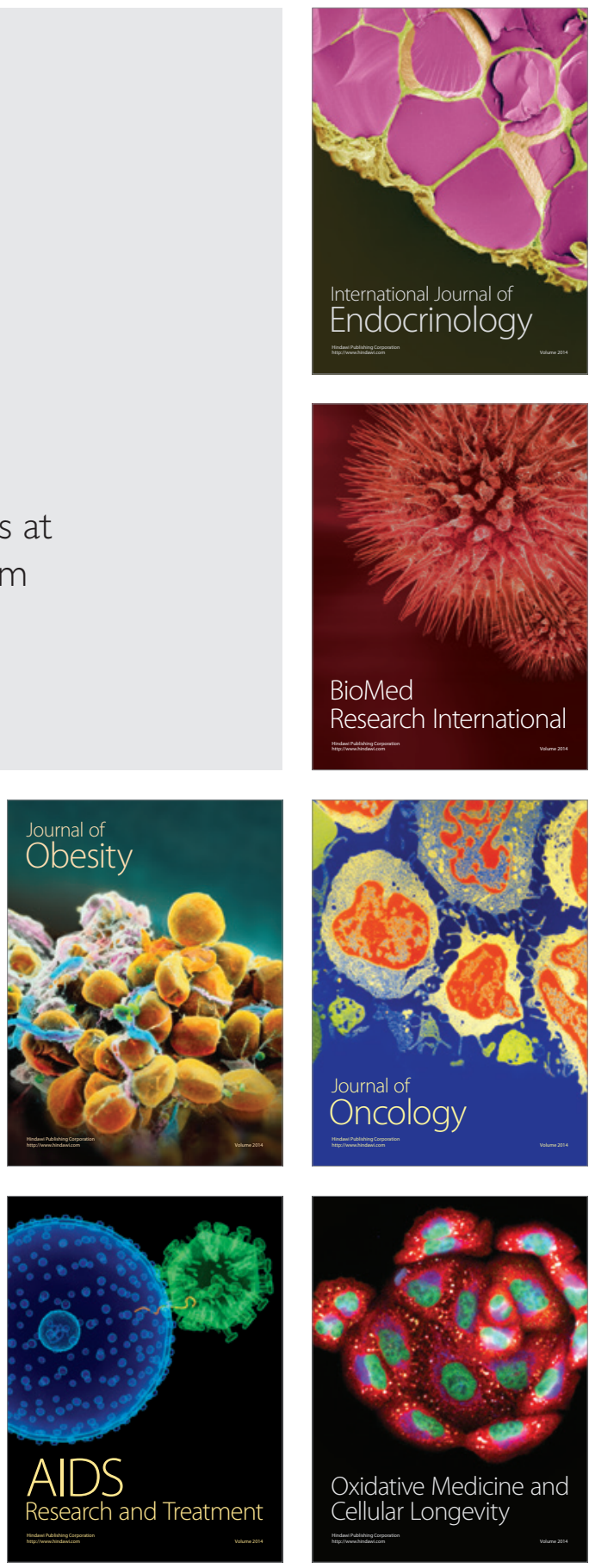